\title{
Roadblock: Is it an Effective Tool Against a Car Bomb?
}

\section{The History of Road-Blocking}

\author{
Luděk RAK ${ }^{1}$
}

\begin{abstract}
This article serves as a short preview to the history of roadblocks (road obstacles), and also as an outlook to modern and future technologies, and challenges they face in this particular field of science. At this moment, it is a real problem to stop the car immediately (if possible), before it causes damages, or threats any civil or military objects. It does not necessarily have to be only an accident, it can be a terrorist attack, which can cause enormous collateral damage and also life losses. The contemporary problem is not only the combat with fire explosive systems, but it is also important to focus on avoiding damaging of important devices, road objects or spots called "soft targets". All this combined presents the essential challenge for roadblocks development.
\end{abstract}

Keywords: roadblock, car bomb, soft target

The history of road-blocking dates back to the times of the Roman Empire expansion, and is associated with its quickly spreading road network. During the existence of ancient Rome, 80,000 km [7] of paved roads and over 400,000 km of roads in total were constructed. The roads were supplemented with numerous structures, bridges and viaducts, the formation line led in side-hill cuttings and trenches, and the roadbed comprised several layers. The layers, methods of construction and the width of the roads were prescribed by law. As basically all Western Europe, the Mediterranean, and the Near East were linked, road security became an issue. Roadblocks were rarely used then, only in frays and combats. Protection more often consisted of the construction of fortification objects on access roads or the roads themselves. On crossroads, villages were founded that were gradually fortified. Where the Roman dominion lasted longer, wooden palisades were turned into stone walls. In border areas, military garrisons were maintained, and the roads passed by fortified buildings-later called “Limes Romanus”.

As the roads could easily be bypassed, road obstacles were not considered practical. In addition, the roads were mainly used for driving cattle and carts or by military units and horsemen. This belief, however, proved false in the late Roman Empire as Teutonic tribes used the roads to move rapidly between provinces raiding various places.

After the fall of Rome, the quality of roads and the highly developed art of constructing and engineering declined. In the following centuries, the transport among newly established feudal states was conducted using the remainders of the Roman roads and mostly earth trade roads. At that time, road obstacles mainly had the form of abatis due to dense forests. In the Czech lands, several cases, when enemy forces were directed, using abatises, to places convenient for the defenders (compare with source [1]), were documented. In mountainous

Ph.D., Captain, assistant professor, Department of Tactics University of Defence; e-mail: ludek.rak@nob.cz 
border areas, felled trees (cut at the height of approx. $1 \mathrm{~m}$ ), mutually stuck and not completely separated from the stumps, meant a significant obstacle for the attacker's movement. Hence, the enemy could only attack along the trade routes, which were protected by lines of fortified settlements, later castles. (A modified variant of this non-demolishing obstacle is used even today.)

All along the history of medieval warfare, both temporary and permanent military organisations were established, whose purpose was to construct roads for carts conveying military materials; these, however, were far from the quality of ancient road constructing.

Between the $15^{\text {th }}$ and $17^{\text {th }}$ century, the quality of road maintenance, construction of bridges and military engineer support improved in Russia first. In the $17^{\text {th }}$ century, due to the transport boom and the invention of explosives other than gun powder, the rest of Europe followed. Only then was the ancient standard of road construction overcome. The need for movement of large military units across Europe led to the establishment of forces dealing with both the construction and the destruction of roads and bridges. Permanent fortifications and bastion forts proved to be inefficient (Franco-Prussian War in 1871), and armies were forced to increasingly manoeuvre, which could be prevented using suitably located obstacles mainly on roads. Also, first fougasses, i.e. predecessors of mines and the first efficient representatives of a later very large group of demolishing obstacles, occurred (Russo-Turkish War 1828-1829). Compare with source [6]. Their massive development came in the late $19^{\text {th }}$ century due to the invention of dynamite and the establishment of factories producing the dynamite, blasting and ammonium nitrate gelatines, burning fuses, explosives and the explosive most important in military terms - Trinitrotoluene (TNT). [8] The use of non-demolishing obstacles boomed during World War I, when road-blocking became one of the crucial engineering tasks. Barbed wire in combination with wooden poles, electric barriers, concertina wires or Czech hedgehogs became the commonly used non-demolishing obstacles that were not only placed between trenches, but were also used for road-blocking on a large scale. The extent of road destruction was classified as:

- demolition-the engineering forces destroyed a line of communication including road structures in order to render the road unserviceable for a certain period of time. After bridges had been demolished by full demolition section, supporting and retaining walls had been destructed, and craters had been placed on roads, it took weeks or even months to restore the road.

- interruption-meant the destruction of minor road structures, damaging of the road formation. The consequences could be remedied within hours or days.

Moreover, abatis, stone barricades, or jammed vehicles with dismounted wheels were still used as barriers.

For the personnel destruction so-called underground torpedoes were mainly used, which were initiated by means of an electric detonator (compare with source [1]), (e.g. Russo-Japanese-War 1904-1905). These were used as separate barriers in the terrain, or as roadblocks preventing the enemy from conveying the ever-heavier cannons, ammunition and other materials. After World War I, anti-tank and anti-personnel mines became one of the main types of demolition obstacles. The first improvised anti-tank mines were introduced around 1917 in the form of artillery ammunition and boxes filled with explosives hidden underground. The charges were usually activated using a hand grenade placed on the top. 
The fact that " $5,500 \mathrm{~km}$ of roads, more than 1,000 bridges and viaducts and 1,000 km of railroads were destroyed” [1: 12] using explosives during the German army retreat shows the extent of the use of demolition obstacles in World War I.

The construction of permanent fortification structures in the inter-war era meant another stage of significant development of non-demolishing obstacles. Forts and strong points were interconnected using wide systems of non-demolishing obstacles in the form of either anti-personnel obstacles-steel needles with the bases embedded in concrete and interconnected by barbed wire-or anti-tank obstacles_-Czech hedgehogs, anti-tank ditches. Roads in border areas were blocked using solid reinforced concrete barriers, and were also guarded by weapons placed in the fort casemates. The trend of heavy fortification structures construction is still apparent at the remainders of Mannerheim, Maginot, so-called Stalin line, Czechoslovak border-area fortification line etc. The demolition obstacles also went through a considerable development. There were two specifically separated ways of anti-tank and anti-personnel mines development, in consequence of which the mines became resistant to removal, i.e. the inventing and upgrading of so-called anti-personnel bounding mine, which exploded after clearing from the casing, and hard-to-remove nonmetal mines continued during World War II and afterwards.

When the benefits of forts proved to be considerably limited with regard to the modern tactics, the development of non-demolishing obstacles began to stagnate. In particular, after World War II, modern influence mines were developed, which were gradually fitted with specific functions using electronics. Non-demolishing obstacles, which had been originally developed for purely military purposes, started to be used in the civil sector due to a growing amount of road transportation and in order to increase road safety. Obstacles, that were to prevent the use of roads, have turned into safety elements aiming to keep a crashing car on the road and reduce the loss to property and lives. Today, crash barriers, shock absorbers [2] and further road equipment must comply with strict standards, and various types of obstacles are particularly important in the field of road safety. Unfortunately, the development of efficient military roadblocks has almost ceased recently, and older types of roadblocks are only being modified. What is more, the obstacles used by the police are usually incapable of stopping a vehicle immediately.

Only the current operations in Afghanistan, Syria and Iraq are proving that the absence of road block development poses a considerable risk in terms of protection against VehicleBorne Improvised Explosive Device (VBIED). “A device placed or fabricated in an improvised manner on a vehicle incorporating destructive, lethal, noxious, pyrotechnic, or incendiary chemicals and designed to destroy, incapacitate, harass, or distract. Otherwise known as a car bomb or VBIED.” [9: GL-11] For requirement this article only in selfpropelled vehicle, which attacked with momentum of mobility and explosive impact (or other lethal possibility).

According to the statistics, the VBIED is the fifth (compare with source [5]) most common method of terrorist attacks in asymmetric operations worldwide. The lack of effective defence makes the terrorist targets quite vulnerable, and accelerated development or the used road elements seem inefficient. (Compare with source [4].)

The use of demolishing obstacles is unjustifiable due to the risk of collateral losses. Furthermore, it cannot be identified in advance, if a moving car diverting from its direction has become a tool of a terrorist attack, or it is an ordinary car accident caused by e.g. 
a driver's acute health problem. Using explosives in that case would be rather inhuman. In addition, maintaining a functional system of demolishing obstacles around a soft target is a utopian and unrealistic concept that means a threat rather than protection.

The non-demolishing obstacles appear to be more appropriate in this case. Yet, today's society pays dearly in a number of incidents of this type all over Europe for having neglected the development of non-demolishing obstacles.

In the worldwide context, the VBIED attacks in Europe have been conducted in an inefficient manner. The terrorists only made use of the kinetic energy of moving vehicles in a "crowd" of people, their acting was not coherent enough, and they had not preselected the locations of their attacks at all, or very randomly. It can be said that if they use explosives in the future, armour their vehicles to secure them against small arms at the minimum, or drive the vehicles using remote control units, the number of casualties will grow dramatically, unless the attack is stopped efficiently. Furthermore, it is clear that the terrorists are capable of producing and using explosive charges even in Europe, as for example in Paris, France close to the "Stade de France" stadium on 15 November, 2015.

In order to prevent such attacks, the process of VBIED preparation must be interfered with, which means the intelligence service shall be involved from the very start, and the police shall conduct their investigation through all stages of the process. All this effort, however, might prove inefficient when it comes to preventing an isolated attack. For that reason, threatened locations of soft targets must be protected using effective nondemolishing obstacles. Due to a great number of soft targets, the obstacles must be cheap, easily transportable, and must have at least partial absorbability as the scatter of splinters during an explosion and their damaging effect is the general substance of the attack. In particular, the ability to stop a vehicle as soon as possible, and the absorbability of the material fragments scattered by an explosive form the limit of survival within the perimeter of the target under attack.

A theoretical chance of an uncovered person standing in an open terrain of surviving a blast wave without the primary and secondary splinters effect is expressed as follows:

$$
r=K(m) \cdot \sqrt[3]{Q}
$$

- $r$-radius from the exploding charge, beyond which the eventuality given by the critical factor $\mathrm{K}(\mathrm{m})$ occurs;

- $K(m)$ - the critical factor of a person's survival 10; for civil buildings the critical factor of destruction is set to 70 , etc.;

- $Q$ - the TNT equivalent of the exploding charge in $\mathrm{kg}$.

Example: When a charge of $10 \mathrm{~kg}$ TNT equivalent explodes, the blast wave lethal radius is $21 \mathrm{~m}$ from the epicentre of the explosion.

Should the obstacle fail to catch the splinters, the zone of lethal effect due to the splinters penetrating targets would expand to:

$R_{(f)}=109.62 \times Q^{0,164}$

[compare with source (3)]

- $R_{(f)}$-Hazardous Fragmentation Distance Range (m);

- $Q$ - the TNT equivalent of the exploding charge in $\mathrm{kg}$.

Considering the above-described case, the distance would be $159 \mathrm{~m}$. 
Hence, even partial absorbability increases the chance of survival within a soft target by more than seven times. The protection against the effects of a blast wave grows considerably with the distance, at which the vehicle is stopped. If, in the case described above, the vehicle is stopped at the target area perimeter at the distance from its centre equal to the radius of destruction, the areal impact on a target area having the size of $2 r$ will decrease to less than $40 \%$. An explosion within the target would destroy $80 \%$ of the area. Thus, with 100 people evenly distributed within a target having the area of $2 r$, only half of the people would be killed by the blast wave effect if compared to an explosion at the target centre.

On these grounds, a specific research is being conducted at the University of Defence, Brno (UNOB) aimed to come up with a project of a non-demolishing obstacle preventing a VBIED attack and to verify its feasibility. The input conditions comprise simple construction, high resistance to VBIED, low price, good transportability and variability. At this stage, steel has been selected as the basic material; in the future, it will be replaced with modern composite armoured plastic. The core of the obstacle is formed by wire ropes with excellent toughness when catching a vehicle and high tearing strength.

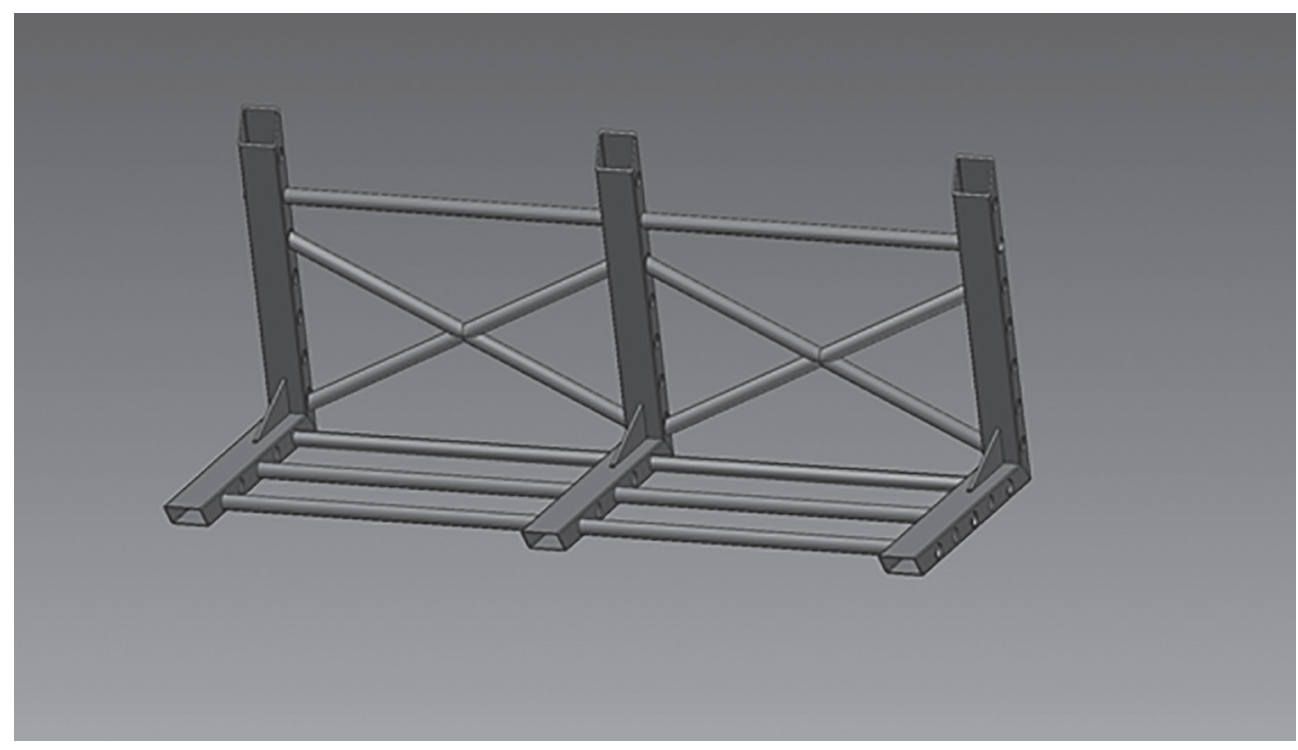

Figure 1. Anti VBIED Obstacle developed by the University of Defence.

[Edited by the author.] 
L. RAK: Roadblock: Is it an Effective Tool Against a Car Bomb?

\section{References}

[1] DOLEZAL, L., KROUPA, L.: Ženijní vojsko, historie a současnost. Praha: Ministerstvo obrany ČR, 2003.

[2] STRIEGLER, R.: Řešení kritických míst na pozemních komunikacích v extravilánu. Brno: Centrum dopravního výzkumu, 2013.

[3] Explosive ordnance disposal procedures (FM60A-1-1-4). Tech. Manual, US ARMY, 2003.

[4] Can concrete barriers protect against truck attacks? Germans stage crash test to find out. $R T$ Question More (online), 22. 03. 2017 www.rt.com/news/384461-truck-attacks-concrete-test/ (Downloaded: 20.11.2017)

[5] Intercenter.com, 18.01.2017. https://intelcenter.com/icd/ / (Downloaded: 18.11.2017)

[6] ŠEVČUK, M. K.: Zdolávání zátarasů. Praha: Naše Vojsko, 1956.

[7] KUCERA, V.: Architektura inženýrských staveb. Praha: Grada Publishing, 2011.

[8] AKHAVAN, J.: The chemistry of explosives. $2^{\text {nd }}$ Edition. Cambridge: Royal Society of Chemistry, 2015.

[9] NATO: Joint Security Operations in Theater (JP-3-10). NATO Standardization Office, 2006. www.bits.de/NRANEU/others/jp-doctrine/jp3_10\%2806\%29.pdf (Downloaded: 30.01.2018) 